\title{
Pendidikan Islam Dalam Perspektif Pendekatan Sosiologi
}

\author{
Seka Andrean*1, Aulia Diana Devi² \\ 1,2UIN Sunan Kalijaga Yogyakarta \\ sekaandrean28@gmail.com, auliadianadevi15@gmail.com
}

\begin{abstract}
Sociological is the approach of the study of education, delivering to understand the relationship of sociology with education. This study aims to find out about Islamic education in the perspective of sociological approach. The research method used is library research, then analyzed and presented the results of data findings objectively. The results showed that the sociology of education has a diverse perspective, in line with the diversity that occurs in the perspective of sociology studies in general. The importance of a sociological approach in understanding religion, because there are many religious teachings related to social problems. The amount of religious attention to this social problem further encourages religions to understand social sciences as a tool to understand their religion. The way of understanding in the approach of the sociology of religion can be easy for those of us who are still too lay because religion is derived also because of social interests. The sociological approach as an educational sociological approach consists of individual approach, social approach, and interaction approach.
\end{abstract}

Keywords: Approach, Islamic Education, Sociology

\begin{abstract}
Abstrak
Sosiologis merupakan pendekatan studi tentang pendidikan, menghantarkan untuk memahami kaitan sosiologi dengan pendidikan. Penelitian ini bertujuan untuk mengetahui tentang pendidikan islam dalam perspektif pendekatan sosiologis. Metode penelitian yang digunakan adalah penelitian studi pustaka (library research), kemudian dianalisis dan disajikan hasil temuan data secara objektif. Hasil penelitian menunjukkan bahwa sosiologi pendidikan memiliki perspektif yang beragam, sejalan dengan keragaman yang terjadi dalam perspektif kajian sosiologi pada umumnya. Pentingnya pendekatan sosiologi dalam memahami agama, karena banyak sekali ajaran agama yang berkaitan dengan masalah sosial. Besarnya perhatian agama terhadap masalah sosial ini selanjutnya mendorong kaum agama memahami ilmu-ilmu sosial sebagai alat untuk memahami agamanya. Cara pemahaman dalam pendekatan sosiologi agama dapat dengan mudah bagi kita yang masih terlalu awam karena agama diturunkan juga karena adanya kepentingan sosial. Pendekatan sosiologi sebagai pendekatan sosiologi pendidikan terdiri dari: pendekatan individual, pendekatan sosial, dan pendekatan interaksi.
\end{abstract}

Kata Kunci: Pendekatan, Pendidikan Islam, Sosiologi

\section{PENDAHULUAN}

Sosiologi pendidikan merupakan ilmu yang berusaha untuk mengetahui cara-cara mengendalikan proses pendidikan untuk mengembangkan kepribadian individu agar lebih baik. Sosiologi pendidikan mengacu pada penerapan pengetahuan sosiologi, teknik berfikir, dan pengumpulan data dalam penyelidikan pendidikan. Dengan demikian sosiologi pendidikan mempelajari tentang proses pendidikan sebagai interaksi sosial, sekolah sebagai kelompok sosial, serta sebagai lembaga sosial.

Sosiologi pendidikan mempunyai manfaat yang besar bagi para pendidik. Sumbangan sosiologi pendidikan adalah memberikan hasil analisis dalam hubungan antar manusia di dalam sekolah dan struktur masyarakat di mana sekolah itu berada. Adapun

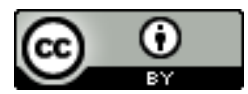

This work is licensed under a Creative Commons Attribution 4.0 International License 
ruang lingkup Sosiologi Pendidikan mengacu pada penerapan pengetahuan sosiologi, teknik berfikir, dan pengumpulan data dalam penyelidikan pendidikan.

Dengan demikian sosiologi pendidikan mempelajari tentang proses pendidikan sebagai interaksi sosial, sekolah sebagai kelompok sosial, serta sebagai lembaga sosial. Model-model analisis sosiologi tentang pendidikan maliputi 4 macam analisis, (1) analisis model struktural fungsional dengan tokohnya Emile Durkeim dan Talcott Parsons, (2) analisi model konflik dengan tokohnya S. Bowles dan H. Gintis dan Louis Althuser, (3) analisis model sosiologi kritis dengan tokohnya Paulo Freire dan Ivan Illich dan (4) Analisis Pendidikan Level Mikro versi Inggris dan Amerika Serikat (Daimah dan Pambudi 2018, 125).

Dalam penerapan pespektif sosiologi dalam menangani pendidikan dijelaskan secara gamblang oleh D.F. Swift. la menunjukkan garis besar tinjauan sosiologi dalam proses pendidikan dalam empat hal, yaitu: (1) Proses pendidikan itu sendiri merupakan suatu interaksi sosial, interaksi atau hubungan timbal balik antara pendidik dan peserta didik, interaksi di antara sesama peserta didik dan lain-lain; (2) Sekolah sebagai kelompok ataupun lembaga (institusi) sosial, yang berisi warga sekolah mulai dari guru, tenaga kependidikan, siswa, dan lain sebagainya; (3) Pengaruh lembaga sosial lain pada lembaga pendidikan, keberadaan skolah/lembaga pendidikan tidak pernah sunyi dari pengaruh lembaga sosial yang lain, seperti ekonomi, politik, agama, dan lain-lain; dan (4) Fungsi lembaga pendidikan bagi masyarakat (Ali 2017, 6-7).

\section{METODE PENELITIAN}

Metode penelitian yang digunakan adalah studi pustaka (Library Research), yakni dengan cara memadukan data dari bermacam-macam sumber literatur dengan caraa meliputi buku-bku, jurnal, prosiding seminar nasional, dan artikel-artikel ilmiah yang berhubungan dengan pendidikan islam dalam perspektif pendekata sosiologis. Sumber data dalam penelitian adalah subjek darimana data dapat diperoleh peneliti (Arikunto 2013, 172). Kemudian, menganalisis serta mengkaji teori-teori yang berkaitan. Penulis menyajikan hasil temuan data secara objektif dan sistematis melalui teknik analisis deskriptif data.

\section{HASIL DAN PEMBAHASAN}

\section{Pendekatan Sosiologis}

Pendekatan dapat didefinisikan cara pandang atau paradigma yang terdapat dalam suatu bidang ilmu. Dalam konteks ini ilmu yang dimaksud adalah ilmu yang digunakan dalam memahami agama. Jalaluddin Rahmat mengatakan bahwa agama dapat diteliti dengan menggunakan berbagai paradigma. Realitas keagamaan yang diungkapkan mempunyai realitas kebenaran sesuai dengan kerangka paradigmanya. Karena itu, tidak ada persoalan apakah penelitian agama itu penelitian ilmu sosial, penelitian legalistik, atau penelitian filosofis (Abdullah dan Rusli Karim 1990, 92).

Sedangkan sosiologi berasal dari bahasa Latin yaitu socius yang berarti kawan, teman, sedangkan logos berarti ilmu pengetahuan. Sosiologi adalah ilmu yang mempelajari fakta-fakta sosial yakni mengandung cara-cara bertindak, berfikir, berperasaan yang berada di luar individu. Sosiologi juga diartikan ilmu yang mempelajari hidup bersama dalam masyarakat dan menyelidiki ikatan-ikatan antara manusia yang menguasai hidupnya itu. Sosiologi mencoba mengerti sifat dan maksud hidup bersama, cara terbentuk, dan tumbuh

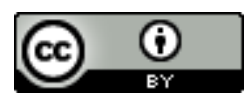


serta berubahnya perserikatan-perserikatan hidup itu serta pula kepercayaannya, keyakinan yang memberi sifat tersendiri kepada cara hidup bersama.

Adapun menurut Soerjono Soekanto, sosiologi diartikan sebagai suatu ilmu pengetahuan yang membatasi diri terhadap persoalan penilaian. Sosiologi tidak menetapkan ke arah mana sesuatu seharusnya berkembang dalam arti memberi petunjukpetunjuk yang menyangkut kebijaksanaan kemasyarakatan dari proses kehidupan bersama tersebut (Soekanto 2001, 21). Walaupun banyak definisi tentang sosiologi, namun intinya sosiologi dikenal sebagai ilmu pengetahuan tentang masyarakat. Sosiologi mempelajari masyarakat meliputi gejala-gejala sosial, struktur sosial, perubahan sosial, dan jaringan hubungan atau interaksi manusia sebagai makhluk individu dan makhluk sosial.

Dari uraian di atas dipahami bahwa pendekatan sosiologis adalah suatu pandangan atau paradigma yang digunakan untuk menggambarkan tentang keadaan masyarakat lengkap dengan struktur, lapisan serta berbagai gejala sosial lainnya yang saling berkaitan. Dengan ilmu ini suatu fenomena sosial dapat dianalisis dengan faktor-faktor yang mendorong terjadinya hubungan, mobilitas sosial serta keyakinan-keyakinan yang mendasari terjadinya proses tersebut. Sosiologi dapat digunakan sebagai salah satu pendekatan dalam memahami agama, hal ini dikarenakan banyak bidang kajian agama yang baru dapat dipahami secara proporsional dan tepat apabila ditelaah dan dikaji melalui pendekatan ini.

Pentingnya pendekatan sosiologi dalam memahami agama, karena banyak sekali ajaran agama yang berkaitan dengan masalah sosial. Besarnya perhatian agama terhadap masalah sosial ini selanjutnya mendorong kaum agama memahami ilmu-ilmu sosial sebagai alat untuk memahami agamanya.

Melalui pendekatan sosiologi akan dapat diapahami dengan mudah, karena agama itu sendiri diturunkan untuk kepentingan sosial. Dalam al-Qur'an misalnya kita jumpai ayahayat berkenaan dengan hubungan manusia dengan manusia lainnya, sebab-sebab yang menyebabkan terjadinya kemakmuran suatu bangsan dan sebab-sebab yang menyebabkan terjadinya kesengsaaraan. Semua itu jelas baru dapat dijelaskan apabila yang memahaminya mengetahui sejarah sosial pada saat ajaran agama itu diturunkan (Rahmat 2002, 38).

\section{Karakteristik Pendekatan Sosiologis}

Sebelum dibahas mengenai macam pendekatan sosiologis, perlu diketahui terlebih dahulu tentang karakterisitik dasar pendekatan sosiologis, yaitu meliputi: (Connoly 2012, 238)

a. Stratifikasi sosial, seperti kelas dan etnisitas.

b. Kategori biososial, seperti seks, gender, perkawinan, keluarga masa kanak-kanak, dan usia.

c. Pola organisasi sosial, meliputi politik, produksi ekonomis, sistem-sistem pertukaran, dan birokrasi.

d. Proses sosial, seperti formasi batas, relasi intergroup, interaksi personal, penyimpangan, dan globalisasi.

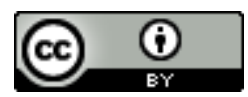


Dari karakteristik di atas, dalam sosiologi terdapat berbagai logika teoritis (pendekatan) yang dapat dikembangkan untuk memahami berbagai fenomena sosial keagamaan. Di antara pendekatan itu yang sering dipergunakan antara lain:

a. Teori fungsionalisme dalam pendekatan sosial dimaksudkan fungsi masing-masing anggota suatu kelompok memberikan pengaruh dalam membentuk integrasi atau disintegrasi kelompok. Apabila setiap anggota kelompok menjalankan fungsinya masingmasing dengan baik, akan membentuk integrasi kelompok dengan baik. Tapi bila ada anggota kelompok tidak menjalankan fungsinya dengan baik, akan menimbulkan disintegrasi dalam kelompok tersebut. Teori fungsionalisme bertujuan untuk meneliti kegunaan lembaga-lembaga kemasyarakatan dan struktur sosial dalam masyarakat. Teori tersebut berpendirian pokok bahwa unsur-unsur yang membentuk masyarakat mempunyai hubungan timbal balik yang saling mempengaruhi, masing-masing mempunyai fungsi tersendiri terhadap masyarakat.

b. Teori konflik dimaksudkan bahwa dengan adanya konflik akan memungkinkan terjadinya integrasi suatu komunitas kelompok, dan juga memungkinkan terjadinya disintegrasi dalam suatu komunitas, tergantung dari sisi mananya konflik itu mau diambil, jika dari sisi positifnya, maka akan membentuk integrasi dan sebaliknya jika dari sisi negatifnya akan membentuk disintegrasi. Teori-teori konflik dapat digunakan untuk menjelaskan kecenderungan integrasi dan disintegrasi yang dialami sebuah sistem sosial. Teori konflik mengasumsikan bahwa masyarakat terdiri dari beberapa kelompok yang memiliki kepentingan satu sama lain. Mereka selalu bersaing untuk mewujudkan hasrat dan kepentingan mereka. Perjuangan untuk mewujudkan hasrat dan kepentingan mereka seringkali bermuara pada terjadinya konflik antara satu komunitas masyarakat dengan komunitas masyarakat lain.

c. Teori interpretatif dimaksudkan bahwa perlu adanya interpretasi dalam setiap melihat fakta-fakta sosial, dari interpretasi itulah memungkinkan adanya pemahaman terhadap suatu komunitas atau suatu bentuk kehidupan sosial.

d. Teori Pertukaran, Salah satu yang dapat digunakan untuk menjelaskan fenomena sosial keagamaan, seperti perubahan dan perilaku sosial ialah teori pertukaran. Menurut teori pertukaran tiada lain ialah melakukan pertukaran yang saling menguntungkan satu sama lain. Menurut perspektif pertukaran, manusia selalu melakukan transaksi sosial yang saling menguntungkan, baik keuntungan materi maupun non materi. Teori pertukaran dapat dijadikan pendekatan untuk menganalisis realitas dan perubahan sosial. Keberadaan suatu komunitas dalam berhubungan dengan komunitas lain atau hubungan antara dalam suatu komunitas akan berlangsung sampai pada suatu titik dimana satu sama lain merasa puas. Perubahan-perubahan yang terjadi dalam sebuah komunitas muslim dapat dipandang dari perspektif pertukaran.

\section{Signifikasi dan Kontribusi Pendekatan Sosiologis}

Pendekatan sosiologi dalam studi Islam, kegunaannya sebagai metodologi untuk memahami corak dan stratifikasi dalam suatu kelompok masyarakat, yaitu dalam dunia ilmu pengetahuan, makna dari istilah pendekatan sama dengan metodologi, yaitu sudut pandang atau cara melihat atau memperlakukan sesuatu yang menjadi perhatian atau masalah yang dikaji (Ridwan. 2001, 110). Metodologi juga bermakna mencakup berbagai teknik yang

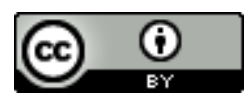


digunakan untuk memperlakukan penelitian atau pengumpulan data sesuai dengan cara melihat dan memperlakukan sesuatu permasalahan atau teknik-teknik penelitian yang sesuai dengan pendekatan tersebut.

Kegunaan yang berkelanjutan ini adalah untuk mengarahkan dan menambah keyakinan-keyakinan ke-Islaman yang dimiliki oleh kelompok masyarakat sesuai dengan ajaran agama Islam tanpa menimbulkan gejolak dan tantangan antara sesama kelompok masyarakat. Seterusnya melalui pendekatan sosiologi dalam studi Islam, diharapkan pemeluk agama Islam dapat lebih toleran terhadap berbagai aspek perbedaan budaya lokal dengan ajaran agama Islam itu sendiri.

Masalah sosial sangat penting di dalam Islam. Hal ini menjadi menarik untuk dipelajari dan dipahami (Khoiriyah 2013,62). Melalui pendekatan sosiologi sebagaimana tersebut di atas terlihat dengan jelas hubungan agama Islam dengan berbagai masalah sosial dalam kehidupan kelompok masyarakat, dan dengan itu pula agama Islam terlihat akrab fungsional dengan berbagai fenomena kehidupan sosial masyarakat. Dari sisi lain terdapat pula signifikasi sosiologi dalam pendekatan Islam, salah satunya dapat memahami fenomena sosial yang berkenaan dengan ibadah dan muamalat. Pentingnya pendekatan sosiologis dalam memahami agama dikarenakan banyak sekali ajaran agama yang berkaitan dengan masalah sosial. Besarnya perhatian agama terhadap masalah sosial ini, selanjutnya mendorong agamawan memahami ilmu-ilmu sosial sebagai alat memahami agamanya.

Melalui pendekatan sosiologis, agama akan dapat dipahami dengan mudah, karena agama itu sendiri diturunkan untuk kepentingan sosial. Dalam al-Qur'an misalnya dijumpai ayat-ayat berkenaan dengan hubungan manusia dengan manusia lainnya, sebab-sebab yang menyebabkan terjadinya kemakmuran suatu bangsa dan sebab-sebab yang menyebabkan terjadinya kesengsaraan. Semua itu hanya baru dapat dijelaskan apabila yang memahaminya mengetahui sejarah sosial pada ajaran agama itu diturunkan (Nata 2012, 41-42).

\section{Pendekatan Sosiologi dalam Pendidikan Islam}

Studi Islam dengan pendekatan sosiologis adalah materi studi Islam yang mempelajari hubungan timbal balik antara agama dan masyarakat.Bagaimana agama mempengaruhi pemikiran dan pemahaman keagamaan.Studi Islam dengan pendekatan sosiologis dapat mengambil beberapa tema.

a. Studi tentang pengaruh agama terhadap masyarakat atau lebih tepatnya masyarakat atau lebih tepatnya pengaruh agama terhadap perubahan masyarakat. Perubahan masyarakat (sosial change) biasanya didefinisikan sebagai perubahan sosial yang meliputi perubahan pada budaya. Struktur sosial dan perilaku sosial dalam jangka tertentu.

b. Studi pola interaksi sosial masyarakat muslim. Studi yang mempelajari pola-pola perilaku masyarakat muslim dengan sesama muslim dan toleransi beragama umat muslim.

c. Studi tentang tingkat pengalaman beragama masyarakat. Digunakan untuk mengevaluasi pola penyebaran agama dan seberapa jauh ajaran agama diamalkan oleh masyarakat (Maruf 2018, 388).

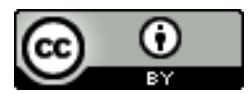


Sosiologi pendidikan sebagai disiplin ilmu pengetahuan yang mempelajari secara khusus tentang interaksi diantara individu-individu, antar kelompok, institusi-institusi sosial, proses sosial, relasi sosial dimana di dalam dan denganya manusia memperoleh dan mengorganisir pengalaman. Menurut Abu Ahmadi, sosiologi pendidikan memiliki pendekatan psiko-pedagogis. Pendekatan sosiologi sebagai pendekatan sosiologi pendidikan terdiri dari pendekatan individual, pendekatan sosial, dan pendekatan interaksi.

\section{Pendekatan Individual (The Individual Approach)}

Dalam sosiologi, individu digunakan untuk menunjuk orang-orang atau manusia perorangan, yang berarti satu manusia bukan kelompok manusia. Individu dibatasi oleh diri sendiri dan tidak terbagi, ibaratnya individu sebagai atom masyarakat, atom sosial. Apabila kita dapat memahami tingka laku individu satu persatu, seperti cara berfikir, perasaan, kemauan, perbuatan, sikap dan ucapannya maka akan dapat dimengerti keberadaan suatu masyarakat.

Pada intinya, individu adalah manusia yang tidak hanya memiliki peranan khas dan lingkungan sosialnya, maliankan juga mempunyai kepribadian serta pola tingkah laku spesifik dirinya, karena dalam diri individu manusia mempunyai tiga aspek, yaitu apek organik jasmani, aspek psikis rohaniah dan aspek sosial kebersamaan. Ketiga aspek tersebut saling mempengaruhi dan keguncangan pada satu aspek akan membawa akibat pada aspek yang lain.

\section{Pendekatan Sosial (The Social Approach)}

Secara pribadi manusia merupakan makhluk individu, tetapi dalam kenyataannya sejak lahir manusia sendiri sebenarnya menunjukkan makhluk sosial. Manusia tidak dapat hidup sendiri tanpa bantuan orang lain. Secara ekstrim, manusia tidak dapat dipisahkan dengan keluarganya, teman, kelompok dan masyarakatnya. Menurut CA. Elwood dalam bukunya The Psycology of Human Society menyatakn bahwa ada 3 unsur biologis yang menyebabkan manusia hidup bermasyarakat dan saling ketergantuungan, yaitu dorongan untuk makan, dorongan untuk mempertahankan diri dan dorongan untuk melangsungkan jenisnya. Pendekataan sosial beranggapan bahwa tingkah laku individu secara mutlak ditentukan oleh masyarakat dan budaya, dimana iindividualitas tenggelam dalam sosialitas manusia.

\section{Pendekatan Interaksi (The Interaction Approach)}

Interaksi sosial adalah suatu hubungan antara dua atau lebih, individu manusia dimana kalakuan individu mempengaruhi, mengubah, atau memperbaiki kelakuan individu lainnya atau sebaliknya. Definidi ini menekankan pada hubunagn timbak balik interaksi sosial antara dua atau lebih manusia. Interaksi sosial dilakukan dengan maksud untuk memenuhi kebutuhan afeksi atau cinta kasih, kkebutuhan inklusiatau mendapatkan kepuasan dan mempertahankan serta memenuhi kebutuhan kontrol. Beberapa faktor yang melatarbelakangi tejadinya interaksi adalah adanya imitasi, sugesti, identifikasi, simpati dan motivasi. Adapun macam-macam interaksi sosial, jika dilihat dari sudut subjeknya, ada tiga macam interaksi sosial yaitu: interaksi antara orang perorangan, interaksi antar orang dengan kelompoknya dan sebaiknya, dan interaksi antar kelompok. Sedangkan jika dilihat

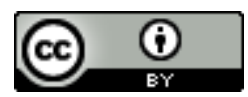


dari segi caranya ada dua macam interaksi sosial yaitu: interaksi langsung yaitu interaksi fisik, seperti berkelahi, hubungan seks/kelamin dan sebagainya dan interaksi simbolik yaitu interaksi dengan mempergunakan bahasa (lisan/tertulis) dan simbol-simbol lain (isyarat) dan lain sebagainya (Efendi 2017, 36-41).

\section{KESIMPULAN}

Pendekatan sosiologis adalah suatu pandangan atau paradigma yang digunakan untuk menggambarkan tentang keadaan masyarakat lengkap dengan struktur, lapisan serta berbagai gejala sosial lainnya yang saling berkaitan. Signifikasi sosiologi dalam pendekatan Islam, salah satunya dapat memahami fenomena sosial yang berkenaan dengan ibadah dan muamalat. Pentingnya pendekatan sosiologis dalam memahami agama dikarenakan banyak sekali ajaran agama yang berkaitan dengan masalah sosial. Besarnya perhatian agama terhadap masalah sosial ini, selanjutnya mendorong agamawan memahami ilmuilmu sosial sebagai alat memahami agamanya.Pendekatan sosiologi sebagai pendekatan sosiologi pendidikan terdiri dari: Pendekatan Individual (The Individual Approach), Pendekatan Sosial (The Social Approach) dan Pendekatan Interaksi (The Interaction Approach).

\section{DAFTAR PUSTAKA}

Abdullah, Taufik, dan Rusli Karim. 1990. Metodologi Penelitian Agama Sebuah Pengantar. Yogyakarta: Tiara Wacana.

Ali, Mohamad. 2017. "Kontribusi Sosiologi Dalam Pengembangan Pendidikan Islam." Suhuf 28 (1): 1-12-12.

Arikunto, Suharsimi. 2013. Prosedur Penelitian Suatu Pendekatan Praktis. Jakarta: Rineka Cipta.

Connoly, Peter. 2012. Aneka Pendekatan Studi Agama. Yogyakarta: LKiS Group.

Daimah, Daimah, dan Setyo Pambudi. 2018. "Pendekatan Sosiologi Dalam Kajian Pendidikan Islam." Jurnal Pendidikan Islam 9 (2): 115-26.

Efendi, Nur. 2017. Islamic Educational Sociology. Jakarta: Rumah Media.

Khoiriyah. 2013. Metodologi Studi Islam. Surakarta: Fataba Press.

Maruf, Amar. 2018. "Pendekatan Studi Islam Dalam Rehabilitasi Penyalahguna Narkoba." Jurnal Tawadhu 2 (1): 381-409.

Nata, Abuddin. 2012. Metodologi Studi Islam. Jakarta: RajaGrafindo Persada.

Rahmat, Jalaludin. 2002. Islam Alternatif. Jakarta: Logos.

Ridwan., M. Deden. 2001. Tradisi Baru Penelitian Agama Islam: Tinjauan Antardisiplin IImu. Bandung: Nuansa.

Soekanto, Soerjono. 2001. Sosiologi Suatu Pengantar. Jakarta: Rajawali Pers.

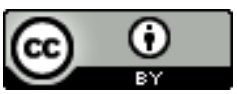

